\title{
Estimation of serum L. casei activity
}

\author{
I. CHANARIN AND VALERIE BERRY \\ From the Medical Research Council Experimental Haematology Research Unit and \\ Department of Haematology, Wright-Fleming Institute of Microbiology, \\ St. Mary's Hospital Medical School, London
}

SYNOPSIS Measurement of the serum Lactobacillus casei ('folic-acid') activity is widely used as an index of folic-acid deficiency. Present methods of assay result in recovery of about half the active material in normal serum. A modified method of assay is described which gives higher L. casei values and a clearer distinction between the sera of normal subjects and of patients with folic-acid deficiency.

The assessment of folic-acid deficiency by the microbilogical assay of serum with Lactobacillus casei was introduced by Baker, Herbert, Frank, Pasher, Hutner, Wasserman, and Sobotka (1959). Present methods of assay measure about half the $L$. case $i$ activity in normal serum. As the technique is widely used in the investigation of patients with megaloblastic anaemia, it was thought desirable to publish details of a modified assay procedure which overcomes this problem.

\section{MATERIALS AND METHODS}

PREPARATION OF SERUM An $0 \cdot 1 \mathrm{M}$ phosphate buffer containing $150 \mathrm{mg}$. ascorbic acid per $100 \mathrm{ml}$. at $p \mathrm{H} 6 \cdot 1$ was prepared before each assay. Serum was added to the buffer to give dilutions varying from 1 in 10 to 1 in 150 . The diluted serum was heated at 10 pounds pressure per square inch for 10 minutes and coagulated protein removed by filtration through no. 1 Whatman paper.

With the higher dilutions the serum extract after filtration was sometimes cloudy. In such cases the turbidity of the extract was allowed for by including an uninoculated tube containing serum extract and culture medium in the assay. The turbidity of this tube was subtracted from the mean value of similar inoculated tubes. More recently the $p \mathrm{H}$ of the ascorbate buffer was reduced to 5.7 and this resulted in clear serum extracts. Variations in $p \mathrm{H}$ from 5.7 to $7 \cdot 2$ did not influence the $L$. case $i$ activity of serum extracts.

CULTURE MEDIUM The culture medium was that described by the United States Department of Agriculture (Toepfer, Zook, Orr, and Richardson, 1951).

ORGANISM Lactobacillus casei, N.C.I.B. 8010, was used. In order to obtain minimum growth in tubes with only

Received for publication 4 May 1963. water and culture medium a broth was inoculated in the morning of the assay and removed from the incubator as soon as some turbidity was visible, i.e., within about six hours of inoculation. The organism was washed three times in a single-strength culture medium before inoculation of the assay.

OTHER DETAILS Other details of the assay have been described by Herbert (1961) and by Waters and Mollin (1961). Provided the ingredients used in making the culture medium were initially free of substances supporting the growth of $\mathbf{L}$. casei, the elaborate treatment of glassware recommended was found to be unnecessary. We have found an occasional batch of casein to be contaminated with 'folate-like' compounds and a single batch of glucose was similarly contaminated (Dr. T. Vanier, personal communication).

\section{RESULTS}

EFFECT OF DILUTION IN PREPARATION OF THE SERUM EXTRACT It had been the practice to dilute serum 1 in 10 in preparing serum extracts although further dilution is usually necessary at the time of the assay. The effect of varying the dilution from 1 in 10 to 1 in 150 is shown in Figure 1. Higher $L$. case $i$ values were always obtained when higher dilutions were used, reaching a plateau after a 1 in 70 dilution.

When more ascorbate-phosphate buffer was added to the coagulated proteins removed in preparing the serum extract and the suspension re-autoclaved, considerably more $L$. case $i$ acitivity was recovered. The highest values were obtained by reheating the deposit from the lower dilutions, i.e., far more was obtained from the 1 in 10 deposit than from the 1 in 50 deposit. However, the rise in the $L$. case $i$ activity was only partly accounted for by the recovery of $L$. case $i$ active material from the precipitate and it must be 




FIG. 1. The effect of varying the dilution of serum in the preparation of a serum extract for microbiological assay with $\mathrm{L}$. casei. The results with sera from four normal subjects are shown.

assumed that some of the material was destroyed by heating.

Serum $L$. casei activity assayed at the 1 in 10 and the 1 in 100 dilution in various groups of patients is shown in Figure 2. The effect of dilution is striking in normal subjects, the mean $L$. case $i$ level being 8.9 $\mu \mathrm{mg}$. per ml. at 1 in 10 dilution and $15.8 \mu \mathrm{mg}$. per $\mathrm{ml}$. at 1 in 100 dilution. The range at the 1 in 100 dilution was 8.0 to $31.4 \mu \mathrm{mg}$. per $\mathrm{ml}$.

On the other hand dilution had little effect on the very low values with sera from patients with megloblastic anaemia requiring folic-acid therapy. The results in patients with vitamin B12 deficiency are also shown.

Effect of ascorbate in preserving $L$. casei activity of sera Waters and Mollin (1961) found that the decline of serum $L$. case $i$ activity could be prevented by the addition of ascorbic acid to the serum before freezing. Herbert (personal communication), however, found that the $L$. casei activity of serum was stable in the frozen state. The addition of ascorbate to sera has the disadvantage of rendering these

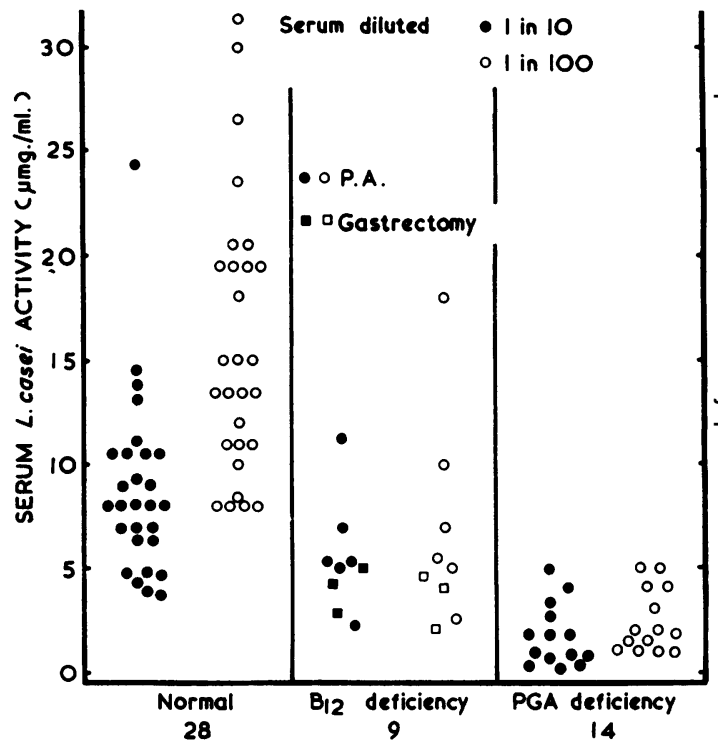

FIG. 2. A comparison of the $\mathrm{L}$. casei activity of serum, when $a 1$ in 10 and $a 1$ in 100 dilution of serum is used in the : preparation of the serum extracts. The sera were obtained from 28 normal subjects, nine patients with megaloblastic anaemia due to $B 12$ deficiency, and 14 patients with megaloblastic anaemia requiring therapy with folic acid.

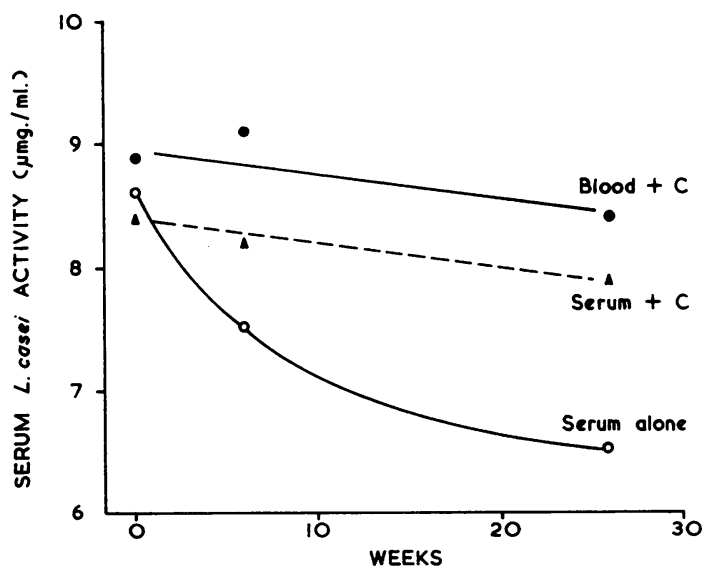

FIG. 3. The effect of storage of sera at $-20^{\circ} \mathrm{C}$. on their L. casei activity. Blood was taken from 30 normal subjects. One portion of blood was added directly to dry ascorbate and serum separated (blood $+C$ ). This procedure caused $\bar{\Phi}$ some haemolysis and this probably produced slightly raised. L. casei values. Serum from the rest of the sample was divided into two and ascorbate added to one portion (serum $+C)$, the remaining serum being stored without preserva- $\triangle$ tive (serum alone). The $\mathrm{L}$. casei activity was assayed periodically during the next six months. Serum extracts were prepared at a 1 in 10 dilution and the mean values of the 30 samples are shown. 
specimens unsuitable for vitamin $\mathrm{B} 12$ assay, since the ascorbate is said to destroy B12 present as hydroxycobalamin. The effect of ascorbate $(5$ to $10 \mathrm{mg}$.) on the preservation of $L$. case $i$ activity was investigated by bleeding 30 normal subjects. The blood sample was divided into three portions. One aliquot was added to a tube with 5 to $10 \mathrm{mg}$. of dry ascorbate and the serum retained. Ascorbate, 5 to $10 \mathrm{mg}$., was added to the serum from the second aliquot. Serum from the third portion was retained without any addition. All the sera were stored at $-20^{\circ} \mathrm{C}$. and $L$. case $i$ activity assayed periodically over the next six months. The results (Fig. 3) confirm the observations of Waters and Mollin (1961) that ascorbate largely prevented the decline of $L$. casei activity in storage.

\section{REFERENCES}

Baker, H., Herbert, V., Frank, O., Pasher, I., Hutner, S. H., Wasserman, L. R., and Sobotka, H. (1959). Clin. Chem., 5, 275.

Herbert, V. (1961). J. clin. Invest., 40, 81.

Toepfer, E. W., Zook, E. G., Orr, M. L., and Richardson, L. R. (1951). Folic acid content of foods. Agriculture Handbook No. 29. United States Department of Agriculture. Govt. Ptg. Off. Washington, D. C.

Waters, A. H., and Mollin, D. L. (1961). J. clin. Path., 14, 335.

\section{Broadsheets prepared by the Association of Clinical Pathologists}

The following broadsheets (new series) are published by the Association of Clinical Pathologists. They may be obtained from Dr. R. B. H. Tierney, Pathological Laboratory, Boutport Street, Barnstaple, N. Devon. The prices include postage, but airmail will be charged extra.

3 The Detection of Barbiturates in Blood, Cerebrospinal Fluid, Urine, and Stomach Contents. 1953. L. C. NICKOlLs. $1 \mathrm{~s}$.

4 The Estimation of Carbon Monoxide in Blood. 1953. D. A. STANLEY. $1 \mathrm{~s}$.

13 The Identification of Serotypes of Escherichia coli Associated with Infantile Gastro-enteritis. 1956. JOAN TAYLOR. 1s.

16 Preservation of Pathological Museum Specimens. 1957. L. W. PROGER. 1s.

17 Cultural Diagnosis of Whooping-cough. 1957. B. W. LACEY. $1 \mathrm{~s}$.

20 Investigation of Porphyrin/Porphyria. 1958 (reprinted 1962). C. RIMINGTON. 2s.

23 The Dried Disc Technique for Bacterial Sensitivity Tests. 1959. R. W. FAIRBROTHER and J. C. SHERRIS. 1s.

24 Safe Handling of Radioactive Tissues in the Laboratory and Post-mortem Room. 1959. R. C. CURRAN. 1s.

26 The Periodic Acid-Schiff Reaction. 1959. A. G. E. PEARSE. 1s.

28 Daily Fatty Acid Excretion. 1960. A. C. FRAZER. 2 s.

29 The Preparation of Bone for Diagnostic Histology. 1960. D. H. Collins. 2s.

30 Control of Accuracy in Chemical Pathology. 1961. G. H. GRANT. 4s.

31 Investigation of Haemorrhagic States with Special Reference to Defects of Coagulation of the Blood. 1961. E. K. BLACKBURN. 4s.

32 Detection of Resistance to Streptomycin, P.A.S., and Isoniazid in Tubercle Bacilli. 1961. R. CRUICKSHANK and S. M. STEWART. 2s.
33 The Laboratory Detection of Abnormal Haemoglobins. 1961. H. LeHMANN and J. A. M. AGER. 4s.

34 Titration of Antistreptolysin O. 1961. H. GOODER and R. E. O. WILliams. $2 s$.

35 The Estimation of Faecal 'Urobilinogen'. 1961. C. H. GRAY. 2 s.

36 Quantitative Determination of Porphobilinogen and Porphyrins in Urine and Faeces. 1961. C. RIMINGTON. 3s. 6d.

37 The Paper Electrophoresis of Serum and Urinary Proteins. 1961. G. FRANGLEN and N. H. MARTIN. 4S.

38 The Augmented Histamine Gastric Function Test. 1961. M. LUBRAN. 2s.

39 Investigation of Haemolytic Anaemia. 1961. J. G. SELWYN. 2 s.

40 Short-term Preservation of Bacterial Cultures. 1962. E. JOAN STOKES. 2s.

41 Serological Tests for Syphilis. 1962. A. E. WILKINsoN. 6s.

42 The Determination of Glucose 6-Phosphate Dehydrogenase in Red Cells. 1962. T. A. J. PRANKERD. 2s.

43 Mycological Techniques. 1962. R. W. RIDDELL. 3s. 6d.

44 The Laboratory Investigation of Catecholamine Secreting Tumours. 1963. M. SANDLER and C. R. J. RUTHVEN. 2 .

45 Diagnostic Test for Hereditary Galactosaemia. 1963. v. SCHWARZ. 2 s.

46 The Determination of Serum Iron and Total Iron Binding Capacity. 1963. A. JORDAN and D. A. PODMORE. 2s. 